caught the yellow and black on the head. We have seen these little fellows in January and marvel at their vitality.

of course, juncos were all over the place during their long period of migration. Fine bits of sand in the driveway seemed to appeal to many of them as they hurried about over the ground.

When I happened to see a downy woodpecker dart around the corner of the porch, stop to look over a lilac bush and then go on to an ash tree before hurrying across the street, I wondered how many other such short visits went unnoticed. Always luck plays an important part in seeing birds.

\title{
BIRDS OF INTEREST
}

\section{THE PIGEON HAUK--}

Commencing early in August there were lulls in the presence of birds around the traps which soon was explained by the sudden flashing by of this small falcon flying swiftly about four feet from the ground. It would dart through the trees, seldom exposing itself when it lit. It was well inside the trees, and did not fly on the outside except when crossing to another part of the grove. Those birds, not already conscious of its presence, would scurry lowly to the nearest protective bush and remain there.

Although I did not see it catch anything, it would seem that no bird, having been spotted by this horror, could possibly escape. After a swift going over of the whole grove, the hawk would disappear, but never failed to pay a periodical visit, extending to the last week in september.

\section{THE DOWNY WOODPECKER}

On October 27th, after all the other birds had seemingly left the area, I heard a tapping sound and found it came from a wren nesting box. A. Downy. Woodpecker was busily engaged in enlarging the small entrance. This was soon accomplished and the box occupied. I waited until dusk, then caught and banded it. This bird takes a $I^{B}$ band, being much smaller than the Hairy Woodpecker which strongly resembles the Downy. It takes a number 2 band. The larger size of the Hairy with larger bill, easily distinguishes it from the Downy.

\section{THE VARIED THRUSH}

With an extra amount of trees around a farmstead on the Prairie, one never know what rare bird may call to rest on the journey during migration.

on the 27 th of september I noticed a bird feeding in front of the traps - a robin-like bird - but there was no mistaking this beautiful one in contrast to the Robin, with its black breast bar, red eyebrow line and wings with bars and spots. It was easily identified as the Varied Thrush. It flew away, but after a short time returned and went straight into a trap. I don't know whether the bird has been seen in Saskatchewan before, but no one would have reason to be in doubt of its identity after seeing and banding it. Later in the day it repeated in another trap a short distance away. Once again I released it, then saw it no more. 


\section{A WATER DRIP}

Dripping water from a pail over a trap with a shallow receptacle to catch it, is the best. Iure to induce a bird to enter a trap. This keeps the water agitated and draws the attention of the birds. Should the dripping cease, there is a noticable lapse. in their capture. "Of course this only applies if there is natural feed. for them. There are times, such as auring the early spring migration, when with no other food available, crushed wheat will suffice along with the water.

\section{OUR WATERFOWL POPUIATION}

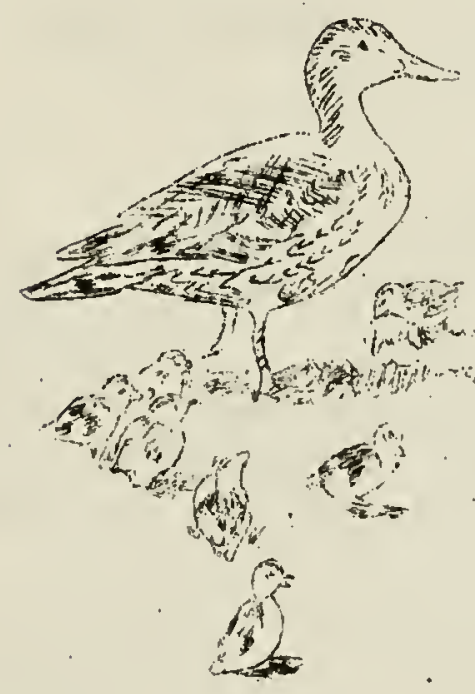

The eleventh annual waterfowl survey of Ducks Unlimited left. Winnipeg on August 28 and returned september 9, after covering the chief concentration areas between Winnipeg and the Athabaska delta in northern Alberta.

The report of the survey by B.W. Cartwright

is most interesting. The following paragraphs from it will give our readers a splendid over-ali picture of conditions in Saskatrhewan.

"On the whole the waterfowl population was excellent and showed a further gain over 1948. The great marshes of the Saskatchewan River deltas east and west of the Pas, which were flooded last year, were back to normal and the waterfowl population was as good as I have seen it - more than making up for rather disappointing numbers in the Winnipegosis area.

We saw more Canvasbacks more widely distributed than I have ever seen on ten previous trips. There was every indication that this favorite species had enjoyed a successful breeding season.

The heaviest waterfowl concentration we encountered on the entire trip was on Lake. Witchekan, the source of Big River, north-west of Prince Albert. We estimated the population of this lake as 50,000 to the mile of shoreline. The extraordinary nature of this concentration may be better appreclated when I say that for 27 miles every foot of shoreline would have to have ducks standing one behind the other ten deep. This works out at one million, three hundred and fifty thousand ducks for this lake alone.

Nearly every sporting..species. was represented, Mallards as usual, being in the majority. On the west shore, however, we saw for several miles, an almost pure concentration of Redheads, the most I have ever seen in one place. Baldpate, Winged Teal, Pintail, Canvasbacks, were present in impressive numbers, and smaller numbers of Blue-winged Teal, Shovellers and Ruday ducks. It was rather hazardous business flying about 100 feet above the mighty throng, in fact, quite often I noticed that we were flying under some' of them and the pilot had to be constantly alert to avoid collisions."

\section{BACKYARD VISITORS}

C. Stuart Houston, who was horne at Yorkton early in september for his holldays, has now returned to Winnipeg for his fourth year in medicine. He reports that his knee is making slow progress but that he is able to get about to his classes and clinics with the aid of canes. 
While at home, although his observations were limited to the backyard, and to several car rides, he prepared for us the following notes of interest:

Grinnell's Water-thrush seen on August 31 in the backyard, and every day till september 3, when it entered one of my traps and was banded. This is the second bird of this species I have banded, in the backyard. In fact, they've visited us twice before - one was seen from August 18 to August 25, 1945, and another was present from August 31 to september 4, 1946. I saw them in their natural summer habitat along the streams up at Nipawin last Spring, and wonder what there is to attract them in the very different habitat of our backyard.

Red-breasted Nuthatch - one noted by Mr. C.C. Shaw on August 31 one in our yard, september 3. (This species has never been noted in Spring in Yorkton, but we have the following fall records: September 19, 1937; Ootober 4 and october 5 (one picked up dead), 1941; October 28, 1942; October 17, 1943.)

White-throated Sparrow - a bird of the year banded september 4. This is my earliest fall arrival date. The previous early date was september 7, and the average, september 12. Of course, this is not too significant, as they nest within 80 miles of Yorkton.

Myrtle Warbler - one banded september 9. (This ties for the previous early date of september 9, 1946. This species is most regular in its first fall arrival; our Yorkton average is september 11.)

On September 4, there were over 2,000 Coots on Upper Rouray Lake, the largest concentration seen there since 1944.

Incidentally, the Water-thrush is a very interesting little bird it walks instead of hops, and wags its tailalmost constantly.

\section{MARYLAND YELIOW THROATS}

Judge I. T. McKim, writes that, on the morning of september 9 , he plcked up thirteen dead Maryland Yellow Throats in the entrance to an old theatre in the business centre of Melfort. Across the street, in front of a hardware store there were about the same number and others were found on both sides of the street. There were between thirty and forty in all. The only explanation he can offer is that they succumbed to three days of cold wet weather. Around the town, at the time, many were still alive.

\section{PINE SISKINS}

Cliff Shaw, of Yorkton, saw seven Pine Siskins on October 3. Two were males and five were females.

\section{A LONE NATURE HIKE IN THE MORNING}

It was between 6.45 and 8.15 on the morning of september 25, when Miss Elizabeth Barker wandered through the beautiful grounds of the Ieglslative Buildings in Regina.

"The splendor of the fall color, surpassing any description by word, coupled with the warm morning air, gave zest to the beauties of the day. Bird species either seen or heard were: House Sparrows, Robins, Meadow Larks, Crows, Horned Larks, Slate-coloured Juncos, Red-breasted Nuthatch, Coukoo, 
Harris Sparrow, Ruby-crowned Kinglet, Say's Phoebe, Yellow-legs, Killdeer and American Goldfinch. The Geese were calling from overhead, while in the Iake from three to four hundred ducks were swimming gaily, gathering their oddments for breakfast.

The Blue Jay and the Canada Jay are not common birds in the Regina area, but Fred Lahrman, of the Provincial Museum staff, was fortunate enough to see both of them on October 8th. He was on a field trip, cemping in Frethy's Coulee, a sheltered valley between Craven and Tregarva. This is about twenty-five miles north-west of Regina.

\section{CRANES AIND EAGLES}

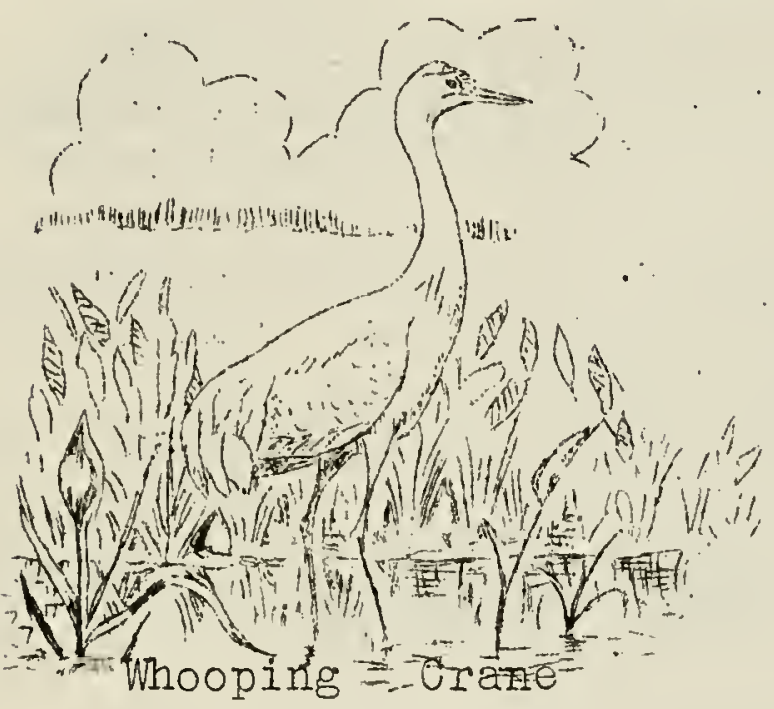

According to Nirs E.C. Boon, of Tulis, a single Whooping Crane was seen in the district on september 24, and on two later occasions. It remained with a group of Sandhill and Little Brown Cranes. Those that saw it were particularly im-. pressed with its imposing size.

There were hundreds of Brown Cranes, but how many were Sandhill and how many Iittle Brown, Mirs. Boon was not able to determine. The smaller ones came in hugo flocks to the dam, but the larger ones preferred to stay in twos and threes.

on september 12, Mir. Boon was going out. with the truck when he saw an eagle swoop down and try to fly off with a crane. They both fell back. As he approached the eagle f'lew off and left the crane. "It 'was dead. There was a hole in its body large enough to put one's finger in. A post mortem showed three ribs broken and the liver torn.: It was an immature Iittle Brown Crane, 28 inches long with a wing-spread of 5 feet 9 inches and weighed 6 and a half pounds.

The eagle left too quickly for positive identification; but because of its large size, and the absence of white markings, Mirs. Boon thought it must have been a Golden Eagle. She explained that several Bald-headed eagles are seen each fall, but never before had she seen a Golden one.

Acting on information received from Mr. Gilchrest, Field Officer of the Department of Natural Resources, a field party from the Provinoial Museum was fortunate enough to watch three Whooping Cranes, as they fed on a stubble field, late in the afternoon of September 29. The field is north of last Mountain lake and west of Hatfield. As they watched they flew south, towards the lake to roost.

"I earnestly suggest that you keep notes and diaries on your nature hobbies. Memories fade or play. you false. A diary is the fact quarry, out of which you can dig materiels in later years.". 


\section{PRAIRIE DOGS \\ HERONS AND GEESE}

Early this summer Mr. and Mrs. Ralph P. Stueck, of Abernethy, motored to Val Marie in order to study and get some pictures of the Prairie Dogs, a colony of which live along the valley of Frenchman Creek. There were not so many in sight as there were two years ago when he and Mr. Albert swanston visited the same area. Only male dögs were seen above the ground. The females, apparently, were attending their young.

"The following day," he writes, "we motored west of Val Marie to the P.F.R.A. Dam No. 2. This is a very suitable sanctuary for Canada Geese, as there are several 1slands which are used at nesting time. As Mr. Swanston and I had procured two Great Blue Herons here in 1947 for the collection of birds and animals which I took to the Toronto National Exhibition, I thought I would examine their colony once more.

After wading through three feet of water to an island, I managed to get to a Heron's nest. It was just like a very large Crow's nest, on top of a large willow bush, about eight or ten feet off the ground. There were four blue eggs about the size of a tame duck egg.

In the near vicinity I counted twelve Heron's nests in the colony. Just at this time I noticed a Canada Gander leaving the island. Knowing the habits of the Canada Goose I immediately called to Mrs. Stueck to focus the field-glasses on this comer, knowing that at nesting time the gander stays within 100 yards of the nest. To our surprise, about eight feet up off the ground was a Canada Goose sitting in the Blue Heron's nest. She had a perfect nest, lined with feathers, quite confortably away from any four-legged predators.

My camera was in the car or a suitable snap could have been taken. She allowed me to come within fifteen feet."

\section{EAII MIGRATIONS}

On September 25, Mr. C.C. Shaw saw a White-crowned Sparrow. This corresponds with Stuart Houston's late date record for Yorkton; September 25, 1938. On September 27, he also saw a White-breasted Nuthatch. Again, according to Stuart's 11st, these are chiefly noted in the Yorkt on area during fall migration.

\section{NIGHTHAWK - INSECT KILIER}

Miss Elizabeth Baker, nature enthusiast and taxidermist of Regina, has verified the fact that Nighthawss are most desirable birds to have around. In this connection she writes:

"On Sunday, september 4, some children fetched the mangled body of a Nighthawk to me. They had picked it up dead in the grass on the outskirts of the town. An examination of the contents of its gizzard revealed no less than the bodies of 32 cutworm moths, 12 medium sized water beetles, 3 Water Boatmen and a number of other soft-bodied insects.

No clue as to the exact cause of 1ts death can be given, but it seems a pity that any of our innocent insect-eating birds should come to their untimely end when they are all so greatly needed to halt the fast rising tide of insect pests of our day." 


\section{HORNED LARKS}

Writing about the early and late nesting habits of these birds in our last issue, Mr. Doug Gilroy asks the question: "How late do they nest?" Miss Barker. has made the following observations which are of interest:

"On May 22 I saw a Lark feeding a pair of well-grown young. The parent larks continued their song in the same vicinity until on July 1 . I suspeoted that more young had hatched nearby, as the mother bird, oblivious of my presence near her, hunted the roads for insects: On July 24 I saw her and a single well grown fledgling resting in the shade just a few steps from where the first young were seen. I have no proof that the bird in each case was the same, but assume that it was."

\section{MIGRATION}

How our feathered friends find their way across pathless areas from continent to continent is one of the mysteries of Nature. They are not taught. For thousands of years their ancestors have followed the same track, and the. desire to follow in it comes as naturally as singing and building of nast. They do not wait until food begins to fail. They reach a certain pitch of strength and contentment. Then desire, ambition and a sudden longing come to them. The little creature, not knowing what stirs in its fluttered breast, takes to the air and sets its course to warmer climes and unknown lands.

And so it was from Sheho. William Niven tells the story:

"Most of the birds have finished their summer season's stay with us, and have departed to more agreeable climes. The nesting season was very favorable this last summer and I think most kinds were very successful with their rearing of broods as many young birds were noted. Many came earlier in the spring than usual, but most species left earlier than usual for the south. The Tree Swallows and Cliff Swallows were gathering on the telephone wires by the middle of July and had all departed by August 1. The Barn Swallows which are generally late nesters, sometimes rearing three broods, only managed two at the most this season. They all ieft in a hurry by the last week in september even although some of the young ones had been flying but a short time. Sometimes they stay right. into october, but the cold dull weather hastened their departure.

A few Robins and Blackbirds were seen in october but they have now moved away. The Tree Sparrows and Juncos were plentiful for awhile - they have also gone. The Nyrtle Warblers were quite common in migration during september and part of october. The severe frosts in carly september followed by very cool weather seemed to start the birds on the way from the north. There were very few stragglers like last fall. I saw a single hawk flying september 9 (species not identified), but they also have followed the others.

on october 24 we had the first real snow, about two inches, followed by several days and nights or very low temperatures. All the lakes were frozen over; ducks of nearly all kinds left; only a few of the hardier species such. as the Golden Eyes, some Bluebills and a very small flock of Mallards were noted in November. The last flock of Whistling Swans departed october 26, about a month earlior than usual. The Canada Geese also left, but they returned again when the weather warmed up. From october 27 to November 7 , fine Indian Sumer weather prevailed and the lakes became clear of ice again. Very few ducks were noted but some geese remained during this period. 


\section{ARRIVAIS}

All the usual winter birds are with us now (November 10). As in the case of the sumer migrants they also arrived earlier than usual. I will list those seen with the first date observed:

\begin{tabular}{|c|c|c|}
\hline gust & 28 & Smith's Longspurs - several days earl \\
\hline Sept ember & 16 & White-throated sparrows \\
\hline ept emb er & 19 & $\begin{array}{l}\text { Slate-coloured Jurcos, Harris Sparrows, Tree Sparrows. (The } \\
\text { last four named are spring and fall migrants but these are early } \\
\text { dates for fall migration.) }\end{array}$ \\
\hline ober & 7 & $\begin{array}{l}\text { Whistling Swans - earliest date ever seen in fall - last seen } \\
\text { date, october } 26 \text {. }\end{array}$ \\
\hline & 1 & One Evening Grosbeak - about 3 weeks before usual time. \\
\hline & 17 & One Pine Grosbeak - one or two weeks earlier than usual. \\
\hline & 19 & an last year. \\
\hline & 20 & Com \\
\hline
\end{tabular}

I hope these early arrivals do not portend an early winter, but in any case it is best to be prepared."

\section{SUNFLOWERS ARE AN ATTRACTION}

As a tip to those who like to feed birds auring the winter, Mr. Niven suggests that sunflowers be left standing all winter, or the heads hung up in a convenient place.

"Of late years," he writes, "I have been in the habit of planting some rows of sunflowers in the garden, partly for windbreak and support for vines. For several years the Goldfinches have been attracted to them, coming every day to eat the seeds until they migrate south. They shell the seeds with their bills and eat the kernels only. As long as there are any left they seem to eat nothing else.

This year, though, for the first time, several other birds started to follow their example. First the Chickadees started coming - they must also have discovered the seeds were good. They. would fly to a hedd and hang upside down, pick out a seed and fly away to a bush to shell and eat it. Then one day (september 9) I noticed two male Red-winged Blackbirds were eating the seeds. That's the first time I ever saw thom eating this kind of seeds. Also a male Purple Finch was coming every day to get his share. All the seed-eating birds seem to be fond of sunflower seeds, once they get the taste of them. They have to learn to shell them, of course, but they soon seem to develop the knack."

\section{WISHEUI THINKIING}

Stuart P. Jordan, of Regina, now attending the University at Saskatoon, writes to tell us how thrilled he is after receiving each copy of the BLUE JAY. He states that without a doubt, this is his favorite magazine and hopes that its publication be continued at all cost. "Possibly," he says, "some wealthy soul w1ll endow the magazine with a substantial sum of money one of these days and then its future will. always be assured - this is only wishful speculation, but such things have happened before." 